\title{
Evolution of Phytological growth activities of Meerut agricultural soil microbes under heavy metal stress
}

\author{
Neha Pal ${ }^{* 1}$, Y. Singh ${ }^{2}$, M.D. Joshi ${ }^{3}$, R. Saxena ${ }^{4}$, N.P. Singh ${ }^{5}$ and Jayanand ${ }^{6}$ \\ ${ }^{4,5}$ Department of Botany, Meerut college, Meerut, U.P \\ ${ }^{1,3,6}$ School of Biological Engineering and Sciences, Shobhit University, Meerut, U.P. \\ ${ }^{2}$ Sr. Radiologists, PGIMER and Dr. RML Hospital, New Delhi \\ *Email: palneha1990@gmail.com
}

\begin{abstract}
Heavy metal pollution of soils is of great concern. The presence of the toxic metal species above critical concentration not only harmfully affects human health but also the environment. Phytoremediation approach using metal accumulating plants is much convincing in terms of metal removal efficiency, but it has many limitations because of slow plant growth and decreased biomass owing to metal-induced stress. Soil microorganisms play a central role in maintaining soil structure, fertility, and in remediating contaminated soils. Rhizosphere, an important interface of soil and plant, plays a significant role in Phytoremediation of contaminated soil by heavy metals, in which, microbial populations are known to affect heavy metal mobility. Phytoremediation strategies with appropriate heavy metal-adapted rhizobacteria have received more and more attention. The supplementation of silicon as nutrient to the plants may play a significant role which includes increase in crop growth and yield, improvement of leaf exposure to light, decreased susceptibility to pathogens and pests and amelioration to abiotic and biotic stresses. The understanding of the beneficial effects of silicon is important to improve crop productivity as it may enhance plant nutritional value for a growing world population.
\end{abstract}

Keywords: Heavy metal pollution, toxic metal species, Phytoremediation, bacterial assisted Phytoremediation, Rhizosphere, rhizobacteria, mobilization of heavy metals.

Paper cited: Pal, N., Singh, Y., Joshi, M.D., Saxena, R., Singh, N.P., and Jayanand. (2017). Urinary Tract Infection Causing Microbes and their Resistance with Antibiotics. South Asian Journal of Food Technology and Environment, 3(1): 480-491.

\section{Introduction}

Agriculture of India is still facing a multitude of problems to maximize productivity to feed the continuously increasing population (Brahman et al., 2013). Farmers are intensifying land use practices without proper nutrient management in their fields which results in nutrient depletion from the soil and it is linked to the decline in crop yield (Meena et al., 2014). Agricultural soil is slightly too moderately contaminated by heavy metal toxicity such as by $\mathrm{Cd}, \mathrm{Cu}, \mathrm{Zn}, \mathrm{Ni}, \mathrm{Co}$, $\mathrm{Cr}, \mathrm{Pb}$ and As. This could be due to long term use of phosphate fertilizers, sewage sludge application, smelters dust, industrial waste and bad watering practices in agricultural lands (Bell et al., 2001; Schwartz et al., 2001; Passariello et al., 2002). Excessive accumulation of heavy metals is toxic to most of the plants. Heavy metals ions are excessively absorbed by roots and translocated to shoot, leading to impaired metabolism and reduce growth (Bingham et al., 1986; Foy et al., 1978). In addition excessive metal concentrations in soil contamination result in microbial activity and fertility of soil and yield losses (McGrath et al., 1995). Waste water in Meerut city runs through a peripheral water stream (Kali nadi) around the city. This water is lifted directly for agriculture purpose. The wastewater stream and agricultural fields near Abdullapur region, irrigated with this waste water is the study area. In the present study we have investigated the heavy metal content of urban waste water, soils and vegetables under cultivation. 


\section{Soil microbes}

a) Types of soil microbes

Soil Flora (Microflora): Bacteria, Fungi, Molds, Yeast, Mushroom, Actinomycetes, Stretomyces, (Algae i.e. BGA, Yellow Green Algae, Golden Brown Algae). Bacteria is again classified in (I) Heterotrophic e.g. symbiotic \& non - symbiotic $\mathrm{N}_{2}$ fixers, Ammonifier, Cellulose Decomposers, Denitrifiers; Autotrophic e.g. Nitrosomonas, Nitrobacter, Sulphur oxidizers, etc. Macroflora: Higher plant roots

Soil Fauna (Microfauna): Protozoa and Nematodes, Macrofauna: Earthworms,Moles, Ants and others.

b) Plant growth promoting bacteria: The beneficial free living soil bacteria that exist in roots association of many different plants which referred to as plant growth promoting rhizobacteria (PGPR) (Kloepper and Schroth, 1978). Depending on their host plants relationship, PGPR divided into two major groups:

(i) Symbiotic rhizobacteria, which may invade the cell interior and inside cell survival (also called intracellular PGPR, example, bacterial nodule), and (ii). Free-living rhizobacteria exist outside plant cells (called extracellular PGPR, e.g., Bacillus, Pseudomonas, Burkholderia, and Azotobacter) (Khan 2005; Babalola and Akindolire, 2011). PGPR can positively influence plant growth and development in three different ways, in that they

a. Synthesize and provide growth promoting compounds to the plants (Glick, 1995)

b. Facilitate the uptake of certain environmental nutrients such as nitrogen, phosphorus, sulphur, magnesium and calcium (Bashan and levanony,1990; Belimov and
Dietz, 2000; Cakmakei et al., 2006), and

c. Decrease or prevent some deleterious effects caused by phytopathogenic organisms or other diseases (Khan et al., 2002; Lugtenberg and Kamilova, 2009).

Generally, rhizobacteria improve growth of plant by synthesizing phytohormone precursors (Ahmad et al., 2008), vitamins, enzymes, siderophores and antibiotics (Burd et al., 2000; Noordman et al., 2006). PGPR also increase plant growth by synthesizing specific enzymes which generates biochemical changes in plants. For example ethylene plays a critical role in various plant developmental processes such as leaf senescence and abscission, epinasty, and fruit ripening (Vogel et al., 1998). Ethylene also regulates node factor signaling, nodule formation, and has primary functions in defense systems of plants. Moreover, as a result of the plant infection by rhizobacteria, ethylene production is increased (Boller, 1991) which at high concentrations will inhibit plant growth and development (Morgan and Drew, 1997; Grichko and Glick, 2001).

\section{Production of Plant Hormones}

Plant hormones are biochemical molecules which are regulating different plant activities. PGPR are also able to produce some of the plant hormones like Auxin and cytokinins. Auxin is among the most important plant hormones affecting growth and development of plant singly orin interaction with the other plant hormones (Miransari et al., 2014; Remans et al., 2007) indicated that the responsiveness of roots of common bean (Phaseolus vulgaris L.) to the presence of Azospirillum brasilense is determined by the Auxin production by the PGPR bacteria. The loci location which was responsible for root responsiveness to production of Auxin by the bacteria was exactly similar to the location of trait loci, which produces root tips under low phosphorus concentration. That is indicating 
there is some kind of interaction between Phosphorus, Auxin and in root formation.

\section{The Advantages of PGPR in Comparison to Chemical Fertilization}

The use of PGPR is superior to chemical fertilization due to the following reasons: (i) they can be used more safely, (ii) more recommendable for economic and environmental conditions, (iii) have used wider range, (iv) much affective in smaller amounts, (v) can be multiplied, however their number is controlled by the activity of plant and other soil microbes, (vi) can contribute to soil organic matter, (vii) can be used under different agricultural practices types including organic farming, (viii) are less subjected to chemical reactions in the soil (Berg, 2009).

\section{Nature and classification of Heavy metals}

The public concern growing over the degenerating quality of the environment has led to a widespread usage when referring to trace elements. Hence, for all practical purposes, other terms such as "trace inorganics," "heavy metals," "microelements," and "micronutrients" have been treated as with the term trace elements (Nagajyoti et al., 2010). The elementary constituents of plant, animal, and human life may be classified as major and trace elements, the latter group including both essential and nonessential elements (including toxic elements). Some of the heavy metals such $\mathrm{Fe}, \mathrm{Cu}$, and $\mathrm{Zn}$ are essential for plants and animals (Wintz et al., 2002).The availability of heavy metals in different medium, and metals such as $\mathrm{Cu}, \mathrm{Zn}$, $\mathrm{Fe}, \mathrm{Mn}, \mathrm{Mo}, \mathrm{Ni}$, and $\mathrm{Co}$ are essential micronutrients (Reeves and Baker, 2000), whose uptake in excess to the plant requirements result in toxic effects (Monni et al., 2000; Blaylock and Huang, 2000). An alternative classification of metals based on their coordination chemistry categorizes heavy metals as class B metals that come beneath nonessential trace elements, which are highly toxic elements such as $\mathrm{Hg}, \mathrm{Ag}, \mathrm{Pb}$, and $\mathrm{Ni}$
(Nieboer and Richardson,1980).Some of these heavy metals are bio-accumulative, and they not break down in the environment nor are easily metabolized. Such metals accumulate in the ecological food chain through uptake at primary producer level and then through consumption at consumer levels. Plants are stationary, and plant roots are the primary contact site for heavy metal ions in soil.

\section{a) Types of heavy metals}

Lead: Lead is naturally occurring, but it is usually released into the environment from artificial sources. It has been mined, smelted, refined and used as an addition in paints and gasoline, leaded pipes, solders, crystals and ceramics (Alberto et al., 2007). Lead concentrations in uncontaminated soils are generally $\mathrm{Ca} \quad 20 \pm \quad 50 \quad \mathrm{mg} / \mathrm{kg}$ (Norrish,1968; Nriagu,1978), Lead addition to agricultural soils in herbicides/ pesticides has been significant in the past with some orchard soils receiving up to $\mathrm{kg} \mathrm{Pb} /$ year resulting in lead concentration in some of these soils exceeding $500 \mathrm{mg} \mathrm{kgy}^{1}$ (Merry et al., 1983).

Mercury: Mercury occurs in a wild range of minerals in the earth's crust, with average crusted concentrations of mercury $-0.08 \mathrm{mg} / \mathrm{kg}$ (Mason and Moore, 1982). It is also associated with $\mathrm{Zn}, \mathrm{Fe}$ and other complex sulphides. Mercury concentrations in limestone are generally $<20 \mathrm{mg}$ kgij1, animal manures may have concentrations of mercury in sludge may range from 5 to $10 \mathrm{mg} / \mathrm{kg}$, and occasionally values of up to 100 mgkgij1 are reported (Steinnes, 1990).

Cadmium: Cadmium concentrations in crystal rocks vary from one to 90,000 $\mathrm{mg} / \mathrm{kg}$ (Page et al., 1981; Cook and Freney, 1998) with igneous and metamorphic rocks generally having lower Cadmium addition to soils varies widely among the countries and the regions within countries (Jensen and 
Bro-Rasmussen, 1992; McLaughin et al., 1996). Cadmium is an important toxic heavy metals and the warning of cadmium pollution health risks was issued initially in the 1970s.

Arsenic: Arsenic is widely distributed into the nature in form of either metalloids or chemical compounds, which causes a variety of pathogenic conditions including cutaneous and visceral malignancies (Matsui et al., 1999).

Selenium: The primary cause of elevated soil selenium is its natural occurrence most often in sedimentary rocks (especially some cretaceous shale) from which seleniferous soils wither (Mayland et al., 1989).

\section{b) Heavy metal-bacteria interactions}

Rhizobacteria have been shown to possess several traits that can alter heavy metals bioavailability (McGrath et al., 2001; Whiting et al., 2001) through the exemption of chelating substances, acidification of the microenvironment, and by influencing changes in redox potential (Smith and Read, 1997). For example, AbouShanab et al. (2003a) reported that the inclusion of Sphingomonas macrogoltabidus, Microbacterium liquefaciens, and Microbacterium arabinogalactanolyticum to Alyssum murale grown in serpentine soil which is significantly increased the plant uptake of Ni when compared with the un-inoculated controls as a result of soil $\mathrm{pH}$ reduction.

c) Toxic effects

Contamination of agricultural soil by heavy metals has become a critical environmental concern being their potential adverse ecological effects. Such toxic elements are considered as soil pollutants due to their widespread occurrence and their acute and chronic toxic effect on plants grown of such soils. The regulatory limits of
Cadmium $(\mathrm{Cd})$ in agricultural soil are $100 \mathrm{mg} / \mathrm{kg}$ soil (Salt et al., 1995). Plants grown in soil containing high levels of Cd display visible symptoms of injury reflected in terms of Chlorosis, growth inhibition, browning of root tip, and finally death (Wojcik and Tukiendorf, 2004; Mohanpuria et al., 2007). High levels of $\mathrm{Zn}$ in soil inhibit many plant metabolic functions; result inmoronic growth and cause senescence. Zinc toxicity in plants limited the growth of both root and shoot (Choi et al., 1996; Ebbs and Kochian,1997; Fontes and Cox,1998). Copper is considered as a micronutrient for plants (Thomas et al, 1998) and plays important role in $\mathrm{CO}_{2}$ assimilations and ATP synthesis. Excess of $\mathrm{Cu}$ in soil plays a cytotoxic role induces stress and causes plants injury. This leads to plant growth retardation and leaf chlorosis (Lewis et al., 2001). Exposure of plants to excess $\mathrm{Cu}$ generates oxidative stress and ROS (Stadtman and oliver, 1991), oxidative stress causes disturbance of metabolic pathways and damage to macromolecules (Hegedus et al., 2001). Chromium (Cr) is a heavy metal that causes genuine environmental contamination in soil, sediments, and groundwater (Shanker et al., 2005). Toxicity of $\mathrm{Cr}$ has been studied in many plants. Toxic effect of $\mathrm{Cr}$ on plant growth and development include alterations in the germination process as well as in the growth of roots, stems and leaves. Hence, expose to high level of $\mathrm{Cr}$ affected total dry matter production and yield of plants (Shanker et al, 2005). Lead (Pb) is one of the ubiquitously distributed most generous toxic elements in the soil. The toxic level of $\mathrm{Pb}$ in soil results from disposal of municipal sewage sludge, mining and smelting activities, $\mathrm{Pb}$ containing paints, pulp and paper, 
gasoline and explosive. High level of $\mathrm{Pb}$ also causes inhibition of enzyme activities, water imbalance, and alterations in membrance permeability and distribs mineral nutrition (Sharma and Dubey, 2005). Toxic effects of $\mathrm{Cr}$ on plant growth and development include alterations in the generation process as well as in the growth of roots, stems and levels. Hence exposure to high level of $\mathrm{Cr}$ affected total cry matter production and yield of plants (Shanker et al., 2005). Arsenate (As) is an analog of Phosphate (P) and completes for the same uptake carries in the root plasma lemma of plants (Meharg and Macnair,1992). Nickel (Ni) is a transition metal and being in natural soils at trace concentrations excepting in ultramafic or serpentinic soils. However, $\mathrm{Ni}^{2+}$ concentration is increasing in certain areas by human activities such as mining works, smelters emission, coal burning and oil, sewage, Phosphate fertilizers and pesticides (Gimeno- Garcia et al., 1996). Exposure of Wheat to high level of $\mathrm{Ni}^{2+}$ enhanced MDA concentration (Pandolfin et al., 1992).

\section{d) Beneficial effects}

The element which promote growth and act as essential are $\mathrm{Al}, \mathrm{Co}, \mathrm{Na}, \mathrm{Se}$, and $\mathrm{Si}$, these elements promote growth of various plant species under certain environmental conditions, however their function and concentration various of plant species (Pilon-Smits Elizabeth et al., 2009). According to Epstein and Bloom (2005) silicon act as a quari-essential element for plants because its deficiency can cause different abnormalities with respect to plant growth, development and reproduction. Silicon is an agronomically essential fertilizer because it enhances plant tolerance capacity to abiotic and biotic stresses
(Liang et al, 2005). Bacillus cladolytrius, Bacillus mucilagenosus, Protens mirabilis, Pseudomonas and Penicillium were found to release silicon, silicate minerals contains $\mathrm{K}$, $\mathrm{Ca}, \mathrm{Mg}, \mathrm{Fe}$ and $\mathrm{Zn}$ and therefore inoculation of silica solubilizing bacteria into the soil may benefit the crop by releasing several nutrients (Muralikannan and Anthomiray,1998). Silicon and Aluminium interact in the soil and form sub-colloidal and inert alumino-silicates and reduce the concentration of phytotoxic aluminium in soil solution (Liang et al., 2007).

e) Mechanism of heavy metal toxicity in plants

The toxicity of heavy metals is manifested in many ways when plant cells accumulate then at high levels heavy metals can be divided into two groups: redox active ( $\mathrm{Fe}, \mathrm{Cu}, \mathrm{Cr}, \mathrm{Co}$ ) and redox inactive $(\mathrm{Cd}, \mathrm{Zn}, \mathrm{Ni}, \mathrm{Al}$, etc). The redox active heavy metals are directly elaborate the redox reaction in cells and result in the formation of $\mathrm{O}^{2-}$ and subsequently in $\mathrm{H}_{2} \mathrm{O}_{2}$ and $\mathrm{OH}$ production via the Haber-Weiss and Fenton reactions (Schutzendubel and Polle, 2002) exposure of plants to redox inactive heavy metals also results in oxidative stress through indirect mechanisms. Such as interaction with antioxidant defense system, disruption of the electron transport chain or induction of lipid peroxidant. The latter can be due to a heavy metal induced increase in lipoxygenase (LOX) activity. Another important mechanism of heavy metal toxicity is the ability of heavy metals to bind strongly to oxygen, nitrogen, and sulphur atoms. This binding affinity is related to free enthalpy of the formation of the product of heavy metal and ligand with low solubility of these products. 
Because of these features heavy metals can inactive enzymes by binding to cysteine residues. For example, Cd binding to sulfhydryl groups of structural proteins and enzymes leads to misfoldings and inhibition of activity and / or interference with redox-enzymatic regulation (Dalcorso et al., 2008; Hall, 2002). Many enzymes use cofactors to work properly for both heavy metals ions (such as $\mathrm{Fe}^{2+}, \mathrm{Mg}^{2+}, \mathrm{Cu}^{2+}, \mathrm{Ca}^{2+}$ ) and organic molecules (such as haem, biotin, FAD, NAD, or Co enzyme A). The displacement of one heavy metal ion by another leads to the inhibition or loss of enzymes activities. Divalent cations such as $\mathrm{Co}^{2+}, \mathrm{Ni}^{2+}$, and $\mathrm{Zn}^{2+}$ displace $\mathrm{Mg}^{2+}$ in ribulose-1-5bisphosphate-carboxylase/ oxygenase (RuBisco) and result in a fall of activity. Displacement of $\mathrm{Ca}^{2+}$ by $\mathrm{Cd}^{2+}$ in Calmodulin, an important protein in cellular signaling, led to the inhibition of Calmodulin-dependent phosphodiesterase activity in radish (Rivetta et al., 1997).

\section{f) Techniques to cure plant species}

Heavy metals cannot be destroyed biologically (no "degradation" change in the nuclear structure of the element shows) but are only transformed from one to another oxidation state or organic complex (Garbisu and Alkorta, 2001) remediation of heavy metal contamination in soil is more difficult.

(i) Phytoremediation: Phytoremediation is an in situ bio mediation process that uses green plants and the microorganisms that are associated with them to extract, sequester, or detoxify pollutants. Plants have the capacity to take up, accumulate, reduce, or eliminate metals, pesticides, solvents, crude oil, and many industrial contaminants. There are many successful examples where phytoremediation has been occupied and where it has been documented to work well for remediating contaminated industrial environments (Macek et al. 2000; Suresh and Ravishankar, 2004). Depending on the method used and contaminated nature involved, phytoremediating areas where metals and other inorganic compounds exist, may utilize one of several techniques (Glick,2003; Newmann and Reynolds, 2004) as follows:

- Phytoextraction, Phytostabilization, Phytostimulation, Phytovolatilization/ Rhizovolatilized, Phytodegradation, Rhizofiltration.

- When research is dedicated to finding optimal hyperaccumulator plants, key study goals should include both (1) evaluating the impact of metal stress on beneficial rhizospheric microbes and crop and (2) concluding the application of bioremediation technologies that could be used to clean up metals from the polluted soils.

(ii) Mobilization of heavy metals: Plants have developed mechanisms by which they can effectively absorb metals from the soil solution and transport them to other parts within the plant. Most metal accumulating species were discovered in which areas having immense metal concentration, and majority of such areas exist in tropical regions for examples, Indian mustard (Brassica juncea) (Salt et al., 1995; Salt and Kramer,1999). Uptake of metals into root cells which is the point of entry into living tissue is a major step in the Phytoextraction process. The mechanisms by which 
metals are absorbed into complex plant root. This process involves transfer of metals from the soil solution to the root surface interface, and then penetration through the membranes of root to root cells. Metal ions cannot move openly across the cellular membrane because of their charge. Therefore, ion transport into cells must be mediated by membrane proteins that have a transport function, and these referred to as transporters. These transporters possess an extracellular domain to which the ions attach just before the transport, and a trans membrane binding structure that comes connects extracellular and intracellular media. This is an oversimplification, and the uptake process complex by nature of the rhizosphere (Laurie and Manthey, 1994).

Table 1: Physicochemical analysis of Kali Nadi water, Abdullapur region, running peripheral to Meerut city

\begin{tabular}{|l|l|l|}
\hline Parameter & September & October \\
\hline $\mathrm{pH}$ & $7.38 \pm(0.81)$ & $7.81 \pm(0.84)$ \\
\hline $\mathrm{Cu}\left(\mathrm{mg} \mathrm{L}^{\prime}\right)$ & $7.54 \pm(1.82)$ & $5.23 \pm(1.05)$ \\
\hline $\mathrm{Cr}(\mathrm{mg} \mathrm{L})$ & $24.23 \pm(5.98)$ & $13.02 \pm(6.32)$ \\
\hline $\left.\mathrm{Cd}(\mathrm{mgL})^{\prime}\right)$ & $18.22 \pm(5.19)$ & $4.54 \pm(4.24)$ \\
\hline $\mathrm{Pb}(\mathrm{mg} \mathrm{L})$ & $11.13 \pm(6.88)$ & $5.32 \pm(6.24)$ \\
\hline $\left.\mathrm{Zn}(\mathrm{mgL})^{\prime}\right)$ & $21.01 \pm(6.44)$ & $8.54 \pm(7.32)$ \\
\hline $\mathrm{Ni}\left(\mathrm{mg} \mathrm{L}^{\prime}\right)$ & $18.32 \pm(8.22)$ & $4.98 \pm(4.72)$ \\
\hline
\end{tabular}

Table 2: Accumulation of heavy metals in vegetables grown in wastewater irrigated soils

\begin{tabular}{|l|c|c|c|c|}
\hline \multicolumn{5}{|c|}{ Metal concentration (mg/ Kg dry weight) } \\
\hline \multicolumn{1}{|c|}{ Vegetable } & Cr & Cd & Pb & Zn \\
\hline Allium cepa L. & $11.82 \pm(5.44)$ & $4.10 \pm(1.97)$ & $11.30 \pm(2.98)$ & $28.32 \pm(7.34)$ \\
\hline $\begin{array}{l}\text { Coriander } \\
\text { saitivum L. }\end{array}$ & $17.23 \pm(6.21)$ & $14.99 \pm(3.98)$ & $20.46 \pm(6.24)$ & $23.22 \pm(8.01)$ \\
\hline $\begin{array}{l}\text { Spinacia } \\
\text { oleracea L. }\end{array}$ & $18.31 \pm(5.45)$ & $24.46 \pm(6.41)$ & $49.92 \pm(8.41)$ & $18.71 \pm(4.04)$ \\
\hline
\end{tabular}

\section{Conclusion}

Plants grow on heavy metal polluted soils resultant in reduction in growth due to changes in their physiological and biochemical activities especially true when the heavy metal involved does not play any beneficial role against the growth and plant development. Thus, it is evident from the several research findings that judicious use and presence of heavy metals having toxic effects on plants after certain limits. There are two aspects on the interaction of plants and heavy metals, one hand; heavy metals show negative effects on plants and other hand, plants have their resistance mechanisms towards toxic effects and for detoxifying heavy metal pollution. Our review showed that both growth and photosynthetic pigments are affected by the presence of heavy metals. The toxicity of heavy metals which is caused by their accumulation in soil can be removed by using hyper accumulator plant through bioremediation/phytoremediation process effectively used for the treatment of heavy metal polluted soil. Plants employ different mechanisms in there mediation of heavy metal polluted soils and Phytoextraction is the most 
common method of phytoremediation used for treatment of heavy metal polluted soils which ensures the complete removal of the pollutant. Microorganisms establish associations with plants and promote plant growth by means of several beneficial characteristics. Finally the search for beneficial bacteria is important for the development of new and efficient inoculants for agriculture. Thus, the introduction of beneficial bacteria in the soil tends to be less impact to the environment than chemical fertilizers, which makes it a sustainable agronomic practice and a way of reducing the production costs.

\section{References}

1. Abou-Shanab, R.A., Delorme, T.A., Angle, J.S., Chaney, R.L., Ghanem, K., Moawad, H., Ghozlan, H.A. (2003a). Phenotypic characterization of microbes in the rhizosphere of Alyssum murale.

International Journal of
Phytoremediation, 5: 3677-379.

2. Ahmad, F., Ahmad, I., Khan, M.S. (2008). Screening of free-living rhizospheric bacteria for their multiple plant growth promoting activities. Microbiological Research, 163:173-81.

3. Alberto, M.R., Arena, M.E., and Manca De Nadra, M.C. (2007). Putrescine production from agmatine by $\mathrm{Lac}$ tobacillus hilgardii; effect of phenolic compounds. Food Control, 18: 898-903.

4. Babalola,O.O. and Akindolire, A.M.(2011). Identification of native rhizobacteria peculiar to selected food crops in Mmabatho municipathy of South Africa. Biological Agriculture and Horticulture, 27(3-4): 294-309.

5. Bashan,Y. and levanony, H. (1990). Current status of Azospirillum inoculation technology: Azospirillum as a challenge for agriculture. Canadian Journal of Microbiology, 36: 591-608.

6. Belimov, A.A., and Dietz, K.J. (2000). Effect of associative bacteria on element composition of barley seedlings grown in solution culture at toxic Cadmium concentrations. Microbiological Research, 155: 113- 121.

7. Bell, F.G., Bullock, S.E.T., Halbich, T.F.J. and Lindsay, P. (2001). Environmental impacts associated with an abandoned mine in the witbank coalfield, South Africa. International Journal of Coal Geology, 45: 195-216.

8. Berg, B. (2009). Qualitative Research Methods for the social sciences. Boston: Allyn \& Bacon, pp.101-157.

9. Bingham, F.T., Pereyea, F.J. and Jarrell, W.M. (1986). Metal toxicity to Agricultural Crop. Metal Ions in Biological Systems, 20:119-156.

10. Blaylock, M.J. and Huang, J.W. (2000). Phytoextraction of metals. In Raskin, I., and Ensley, B.D. (eds). Phytoremediation of toxic metals: using plants to clean up the environment, New York: Wiley, pp. 53-70.

11. Boller, T. (1991). Ethylene in pathogenesis and disease resistance. In: Suttle, J.C. and Matto, A.K. (eds) The Plant hormone ethylene CRC Press, BocaRaton, FL, PP293-314.

12. Brahman, P.S., Kumar, A., Ghosh, S., Roy Chawdhury, S., Singandhupe, R.B., Singh, R., Nanda, P., Chakraborthy, H., Srivastava, S.K. and Benera, M.S.(2013). Challenges to food security in India. Current Science, 104 (7): 841846.

13. Burd, G.I., Dixon, D.G. and Glick, B.R. (2000). Plant growth promoting bacteria that decrease heavy metal toxicity in plants. Canadian Journal of Microbiology, 46: 237-245.

14. Cakmakei, R., Donmez, F., Aydm, A. and Sahin, F. (2006). Growth promotion of plants by plant growth promoting rhizobacteria under green house and two different field soil conditions. Soil Biology \& Biochemistry, 38: 1482-1487.

15. Choi, J.M., Pak, C.H. and Lee, C.W. (1996). Micronutrient toxicity in French 
Evolution of Phytological growth activities of Meerut agricultural soil microbes under heavy metal stress

marigold. Journal of Plant Nutrition, 19: 901-916.

16. Cook, P.J., and Freney (1998). Sources of Cadmium in agriculture- sediments, groundwater, fertilizers and other additives. In: Simpson, J. and Curnow, W. (Ed.) Cadmium Accumulations in Australian Agriculture. Bureau of Rural Resources Proceedings No.2, Australian Government Publishing Service, Canberra, Australia, 6-19.

17. Dalcorso, G., Farinati, S., Maistri, S., and Furini, A. (2008). How plants cope with Cadmium: Staking all on metabolism and gene expression. Journal of Integrative Plant Biology, 50(10): 1268-1280.

18. Ebbs, S.D. and Kochian, L.V. (1997). Toxicity of zinc and copper to Brassica species: implications for phytoremediation. Journal of Environmental Quality, 26: 776-781.

19. Epstein, E. and Bloom, A.J. (2005). Mineral Nutrition of plants: Principles and perspectives $\left(2^{\text {nd }}\right.$ ed.), Sinauer, Sunderland, MA.

20. Fontes, R.L.S. and Cox, F.R. (1998). Zinc toxicity in Soybean grown at high iron concentration in nutrient solution. Journal of Plant Nutrition, 21: 17231730.

21. Foy, C.D., Chaney, R.L. and White, M.C. (1978). The physiology of metal toxicity in plants. Annual Review of Plant Physiology, 29(1): 511-566.

22. Garbisu, C. and Alkorta, I. (2001). Phytoextraction: A cost-effective plant based technology for the removal of metals from the environment. Bio resource Technology, 77: 229-236.

23. Gimeno-Garcia, E.V., Adreu V.I. and Boluda, R.A. (1996). Heavy metals incidence in the application of inorganic fertilizers and pesticides to rice farming soils. Environment Pollution, 1:19-25.

24. Glick, B.R. (1995). The enhancement of plant growth by free- living bacteria.
Canadian Journal of Microbiology, 41: 109-117

25. Glick, B.R. (2003). Phytoremediation: synergistic use of plants and bacteria to clean up the environment. Biotechnology Advances, 21: 383-393.

26. Grichko, V.P., and Glick, B.R. (2001). Amelioration of flooding stress by ACC deaminase containing plant growth promoting rhizobacteria. Plant Physiology and Biochemistry, 39: 11-17.

27. Hall, J.L. (2002): Cellular mechanisms for heavy metal detoxification and tolerance. Journal of Experimental Botany, 53(366): 1-11.

28. Hegedus, A., Erdei, S. and Horvath, G. (2001). Comparative studies of $\mathrm{H}_{2} \mathrm{O}_{2}$ detoxifying enzymes in green and greening barley seedlings under cadmium stress. Plant Science, 160: 1085-1093.

29. Jensen, A. and Bro-Rasmussen, F.(1992). Environmental cadmium in Europe. Reviews of Environmental Contamination and Toxicology, 125:101-181.

30. Khan, A.G. (2005). Role of soil microbes in the Rhizospheres of plants growing on trace metal contaminated soils in phytoremediation. Journal of Trace Elements in Medicine and Biology, 18: 355-364.

31. Khan, M.S., Zaidi, A. and Aamil, M. (2002). Biocontrol of fungal pathogens by the use of plant growth promoting rhizobacteria and nitrogen fixing microorganism. Journal of the Indian Botanical Society, 81: 255-263.

32. Kloepper, J.W. and Schroth, M.N. (1978). Plant growth promoting rhizobacteria on radishes. Proceeding of fourth International Conference on Plant Pathogen Bacteria, Angers, France. Vol. 2: 879-882.

33. Laurie, S.H. and Manthey, J.A. (1994). The chemistry and role of metal ion chelation in plant uptake processes. In: Mantbey, J.A., Crowley, D.E. and 
Luster, D.G. (Eds), Biochemistry of metal micronutrients in the rhizosphere. Lewis Publishers, Boca Raton, pp 165182.

34. Lewis, K., Li, C., Perrin, M.H., Blount, A., Kunitake, K., Donaldson, C., Vaughan, J., Reyes, T.M., Gulyas, J. and Fischer, W. (2001). Identification of urocortiin $3^{\text {rd }}$, an additional member of the corticotropin-releasing factor (CRF) family with high diffinity for the CRF2 receptor. ProcNaH, Acad, Sci USA 98:7570-7575.

35. Liang, S., Stroere, J., and Box, J.L. (2005). Mapping daily snow/ice shortwave broadband albedo from Moderate Resolution Imaging Spectroradiometer (MODIS): The improved direct retrieval algorithm and validation with Greenland in situ measurement. Journal of Geophysical Research, 110.doi.10.1029 / 2004JD005493.

36. Lugtenberg, B. and Kamilova, F. (2009). Plant growth promoting rhizobacteria. Annual Review of Microbiology, 63: 541-556.

37. Macek, T., Mackova, M. and Kas, J. (2000). Exploitation of plants for the removal of organics in environmental remediation. Biotechnology Advance, 18: 23-34.

38. Mason, B. and Moore, C.B. (1982). Principle of Geochemistry, John Wiley, New york. pp.344.

39. Matsui, M., Nishigori, C., Toyokuni, S., Takada, J., Akaboshi, M. and Ishikawa, M. (1999). The role of oxidative DNA damage in human arsenic carcinogenesis: Detection of 8-hydroxy2-deoxyguanosine in arsenic- related Bowen's disease. Journal of Investigative Dermatology, 113:26-31.

40. Mayland, H.F., James, L.F., Panter, K.E. and Sonderegger, J.L. (1989). In: Jacobs, L.W. (Ed), Selenium in Agriculture and the Environment. Soil Sci. Soc. Am. Spec. Pub. No. 23. ASA, SSSA, Madison, WI. Pp. 15-50.
41. McGrath, S.P., Chaudri, A.M. and Giller, K.E. (1995). Long term effects of metals in sewage sludge on soils, microorganisms, and plants. Journal of Industrial Microbiology, 14: 94-104.

42. McGrath, S.P., Zhao, F.J. and Lombi, E. (2001). Plant and rhizosphere process involved in phytoremediation of metal contaminated soils. Plant Soil. 232(1/2): 207-214. doi: 10.1023/A: 1010358708525.

43. McLaughin, M.J., Tiller, K.G., Naidu, R. and Stevens, D.G. (1996). Review: The behaviour and environmental impact of contaminants in fertilizers. Australian Journal of Soil Research, 34:1-54.

44. Meena, V.D., Dotaniyan, M.L., Coumar, V., Rajendiran, S., Kundu, A.S. and Rao, A.S. (2014). A case for silicon fertilization to Improve Crop Yields in Tropical soils. Proc. Natl. Acad. Sci., India, Sect. B Biol. Sci. (July-Sept 2014). 84 (3): 505-518.

45. Meharg, A.A. and Macnair, M.R.(1992). Suppression of the high affinity phosphate-uptake system: A mechanism of arsenate tolerance in Holcus lanatus L. Journal of Experimental Botany, 43: 519-524.

46. Merry, R.H., Tiller, K.G. and Alston, A.M. (1983). Accumulation of copper, lead, and arsenic in Australian orchard soils. Australian Journal of Soil Research, 21: 549-561.

47. Miransari, M. and Smith, D. (2014). Plant hormones and seed germination. Environmental and Experimental Botany, 99: 110-121.

48. Mohanpuria, P., Rana, N.K. and Yadav, S.K. (2007). Cadmium induced oxidative stress influence on glutathione metabolic genes of Camellia sinesis (L.) O. Kuntze. Environmental Toxicology, 22: 368-374.

49. Monni, S., Salemma, M. and Millar, N. (2000). The tolerance of Empetrum 
nigrum to copper and nickel. Environmental Pollution, 109: 221-229.

50. Morgan, D.W. and Drew, C.D. (1997). Ethylene and plant response to stress. Physiologiae Plantarum, 100: 620-630.

51. Muralikannan, N. and Anthomiray, S. (1998). Occurrence of silicate solublising bacteria in rice ecosystem. Madras Agricultural Journal, 85(1): 4750 .

52. Nagajyoti, P.C., Lee, K.D. and Sreekanth, T.V.M. (2010). Heavy metal, occurrence, and toxicity for plants: a review. Environmental Chemistry Letters, 8: 199-216. doi: 10.1007/s 10311-010-0297-8.

53. Newmann, L.A. and Reynolds, C.M. (2004). Phytodegradation of organic compounds.

Current Opinion in Biotechnology, 15: 225-230.

54. Nieboer, E. and Richardson, D.H.S. (1980). The replacement of the nondescript term heavy metals by a biologically and chemistry significant classification of metal ions. Environmental Pollution, Series B, 1:326.

55. Noordman, W.H., Reissbrodt, R., Bongers, R.S., Rademaker, I.L.W., Bockelmann, W. and Smit, G. (2006). Growth Stimulation of Brevibacterium sp by Siderophores. Journal of Applied Microbiology, 101: 637-646.

56. Norrish, K. (1968). Some phosphate minerals in soils. Trans. $9^{\text {th }}$ Int. Congr. Soil Sci., Adelaide II: 713-723.

57. Nriagu, J.O. (1978). Lead in soils, sediments, and major rock types. In: Nriagu, J.O. (Ed.), The Biogeochemistry of lead in the environment-Part A. Elsevier, Amsterdam. pp. 15-72.

58. Page, A.L., Bingham, F.T. and Chang, A.C. (1981). Cadmium. In: Lepp, N.W. (Ed.), Effect of Heavy metal pollution on plants (Vol. 1): Effects of Trace Metal on Plant Function. Applied Science, London. Pp. 77-109.
59. Pandolfin, T., Gabbrielli, R. and Comparini, C. (1992). Nickel toxicity and peroxidase activity in seedlings of Triticum aestivum L. Plant cell and Environment, 15: 719-725.

60. Passariello, B., Giuliano, V., Quaresima, S., Barbaro, M., Caroli, S., Forte, G., Garelli, G. and Iavicoli, I. (2002). Evaluation of the environmental condition at an abandoned mining site. Microchemical Journal, 73: 245-250.

61. Pilon-Smits Elizabeth, A.H., Quinn, C.F., Tapken, W., Malagoli, M. and Schiavon, M. (2009). Physiological functions of beneficial elements. Current Opinion in Plant Biology, 12: 267-274.

62. Reeves, R.D. and Baker, A.J.M. (2000). Metal accumulating plants. In: Raskin, I. and Ensley, B.D. (ed.), Phytoremediation of toxic metals: using plants to clean up the environment. New york, NY, USA: John Willey and sons, 193-229.

63. Remans, R., Croonenborghs, A., Gutierrez, R.T., Michiels, J. and Vanderleyden, J. (2007). Effects of plant growth promoting rhizobacteria on nodulation of Phaseolus vulgaris L-are dependent on plant $\mathrm{P}$ nutrition. European Journal of Plant Pathology, 119:341-351.

64. Rivetta, A., Negrini, N. and Cocucci, M. (1997). Involvement of $\mathrm{Ca}^{2+}$ Calmodulin in $\mathrm{Cd}^{2+}$ toxicity during the early phases of radish (Raphanus sativus L.) seed germination. Plant Cell and Environment, 20(5): 600-608.

65. Salt, D.E. and Kramer, U. (1999). Mechanisms of metal hyperaccumulation in plants. In: Raskin, I. and Ensley, B.D. (ed.), Phytoremediation of toxic metals: using plants to clean up the environment. John Wiley and sons, New York, pp 231-246.

66. Salt, D.E. and Rauser, W.E. (1995). Mg ATP dependent transport of phytochelatins across the Tonoplast of 
Oat roots. Plant Physiology, 107: 12931301.

67. Schutzendubel, A. and Polle, A. (2002). Plant responses to abiotic stresses: heavy metal induced oxidative stress and protection by mycorrhization. Journal of Experimetal Botany, 53:1351-1365.

68. Schwartz, C., Gerard, E., Personnet, K. and Morel, J.L. (2001). Measurement of in-situ phytoextraction of zinc by spontaneous metallophytes growing on a former smelter site. Science of the total Environment, 279: 215-221.

69. Shanker, A.K., Cervantes, C., LozaTavera, H. and Avudainayagam, S. (2005). Chromium toxicity in plants. Environment International, 31: 739-753.

70. Sharma, P. and Dubey R.S. (2005). Lead toxicity in plants. Brazilian Journal of Plant, 17(1): 35-52.

71. Sharples, J.M., Meharg, A.A., Chambers, S.M. and Cairney, J.W.G. (2000). Evolution: Symbiotic to arsenic contamination. Nature, 404: 951-951.

72. Smith, S.E. and Read, D.J. (1997). Mycorrhizal symbiosis. $2^{\text {nd }}$ ed. Academic Press, London.

73. Stadtman, E.R. and Oliver, C.N. (1991). Metal Catalyzed oxidation of proteins. Journal of Biological Chemistry, 266: 2005-2008.

74. Steinnes, E. (1990). Effects of natural ionizing radiation. In: Lag, J. (Ed.), Geomedicine. CRC Press. Boca Raton. FL. pp. 163-169.

75. Suresh, B. and Ravishankar, G.A. (2004). Phytoremediation-a novel and promising approach for environmental clean-up. Critical Reviews in Biotechnology, 24: 97-124.

76. Thomas, F., Malick, C., Endresze, E.C. and Davies, K.S. (1998). Distinct responses to copper stress in the halophyte, Mesembryan-Themum Crystallium. Physiologia Plantarum, 102: 360-368.

77. Vogel, J.P., Garvin, D.F. and Leong, O.M. (2006). Agrobacterium-mediated transformation of Brachypodium distachyon inbred line development in the model grass Brachypodium distrachyon. Plant Cell Tissue and Organ Culture, 84: 100179-100191.

78. Whiting, S.N., de Souza, M.P. and Terry, N. (2001). Rhizosphere bacteria mobilize $\mathrm{Zn}$ for hyperaccumulation by Thlaspi caerulescens. Environmental Science and Technology, 35(15): 31443150. doi 10.1021/es001938v.

79. Wojcik, M. and Tukiendorf, A. (2004). Phytochelatin synthesis and Cadmium localization in wild type of Arabidopsis thaliana. Plant Growth Regulations, 44: 71-80.

\begin{tabular}{|ll|}
\hline Received & : May 2017 \\
Revised & : May, 2017 \\
Published & : June, 2017 \\
& \\
\hline
\end{tabular}

